\title{
Education Management and Guarantee System of Physical Education Students with Domestic Economic Difficulties
}

\author{
GangLi $^{1, a}$, YanCheng ${ }^{2, b}$ \\ ${ }^{1}$ Institute of Physical Education, Shandong University of Finance and Economics, \\ Shandong, 250014,China. \\ ${ }^{2}$ Shandong Analysis and Test Center, Shandong,250014, China. \\ aemail: Lg0224shi@163.com, bemail:chengyan99@163.com
}

Keywords: family financial difficulties; physical education; education; support system

\begin{abstract}
With the deepening of the reform and development of higher education in our country, especially reform of the charging system, groups of college students with financial difficulties are also rapidly expanding.Physical education students with families financial difficulties in the university campus has become a important part of social poverty, and their living conditions have attracted the attention of national, school and society.Through methods of paper documentation, comprehensive analysis, the group characteristics and the causes were studied, and from the "financial assistance" and "spiritual support" ways to education management, and on that basis to build a new model of college students with family financial difficulties in order to safeguard the family poor students equal access to education and improve the overall quality of our population.
\end{abstract}

\section{Introduction}

Since in the 1980 of the 20th century, with the reform of China's higher education investment system, the non-obligatory nature of higher education has been highlighted, and the university fees were subject to cost-sharing. Because of the imbalance of China's economic development and income disparities, and now partially State-owned enterprise workers laid off as a result of the reform of economic and other reasons, so some relatively poor families cannot afford the high costs of higher education, and there have been a number of significant numbers of poor students. In this context, study on educational management and funding issues on economic difficulties of physical education students in colleges and universities will be a hotspot.

\section{The group characteristics and the causes of physical education students with family financial difficulties}

1.1 The group characteristics of physical education students with family financial difficulties

(一) Living simply, working hard, stressful learning and training

Most poor students in colleges and universities understand that life is not easy, life relatively simple, and three meals a day steamed bread and pickles to eat. These students with life's tough are properly aware of their situation and work harder than other students, so they can achieve excellent results.

(二) Mental burden and poor social interaction abilities

The economy gap between university students growing are more and more obvious, which caused the students ' psychologica imbalance with economic difficulties. They feel depressed, lonely and bored,and outward manifestation of eccentric loner, afraid to close, often working alone and poor social skills.

(三) Top dependent psychology

Some students with domestic economic difficulties felt that access to finance is a right, even more, they want many funds. And they did not think to improve their living conditions through their own efforts.

1.2 The causes of physical education students with domestic economic difficulties 


\section{(一) Family and personal reasons}

The family poverty is the primary cause of students with economic difficulties. Families provide most of the basic conditions for survival and development. Unexpected events, diseases, the natural conditions of family seat, and the lack of resources would lead to economic difficulties. Minority college students with domestic economic difficulties can not strive to become stronger and support oneself when facing various constraints, and even very few cultivate the habit of extravagance.These burden the parents, also will put themselves into long-term poverty.and styled. Do not use hard tabs, and limit use of hard returns to only one return at the end of a paragraph. Do not add any kind of pagination anywhere in the paper. Do not number text heads-the template will do that for you.Finally, complete content and organizational editing before formatting. Please take note of the following items when proofreading spelling and grammar:

(二) Social reasons

The formation of college students with financial difficulties has a complex social reasons, mainly including low per capita amount of educational resources, the gap widening, imbalance of regional economic development,and the cost of education increases.

\section{Study of educational management of physical education students with family financial difficulties}

2.1 The current situation of educational management of physical education students with family financial difficulties

(一) Achievements

(1) Continuous improvement of the national student loans

In 2006,ministry of education, ministry of finance, people's Bank, China banking regulatory commission jointly issued a declaration on further improving the work of national student loan advice, which supplemented and perfected the management measures. National student loan policy has become the largest, most elaborate and largest beneficiary of a policy.

(2) Normalization of scholarship student function.

In 2002, ministry of education began to set up "National Scholarship". In 2007, our country for students with financial difficulties establish special "national motivational scholarship" ,and the finance noodleswere on average about $20 \%$ of total number of students about undergraduate colleges and universities throughout the country.

(3) Significant effects of other methods of financing

During this period, the establishment of other means of funding are: general business credit, "green passage", "the free education of normal university students in six colleges".These policies are a useful supplement to national policy on financing.

\section{(二) Shortcomings}

The current financing system has the problems of the unperfect financial aids and the weak spiritual support. In terms of solving the economic problems, first, the funding level cannot meet the needs of students with financial difficulties;second, the progress is uneven;third, complementary support measures is not perfect; fourth, policy was lack of predictability.

2.2 The educational management measures of physical education students with family financial difficulties

(一) Adequate financing from economics

The main cause of poor students with psychological risks is economic poverty. Therefore, we must first do financial aid, and provided a platform for extensive financial support for poor students to help them out of the closed circle. Through improving their study and living, so that they can grow up healthily.

(二) correct guidance from mentals

Poor students is not just a question of money.We should give them economic assistance, at the same time schools have to vigorously strengthen ideological and political education of the poor students, and develop the "moral support" project. 
We should increase the visibility of self-empowerment example for poor students, self-empowerment in advocacy but also should provide some guidance and reference for poor students, giving moral encouragement and practice

(三) actively encourage from learning

"The poor children early masters". Majority of poor students ' minds are more mature and pragmatic, and these students have a strong self-motivated, work very hard, active organizations involved in various activities, in practice to constantly enrich and enhance themselves.

(四) humanistic care on the psychological

We should approache poor students d in several ways, and communicate with them, and help them resolve psychological pressure. We should help poor students to establish correct world outlook, outlook on life, and values, and encourage them to not bow in front of dilemma, face difficult, aggressive, brave, cultivation of good psychological quality, so as to continuously improve the poor students ' mental capacity.

\section{Study on financial aid system of physical education students with family financial difficulties}

3.1 Existing financial aid system

Current student funding system was beginning to take shape, including scholarships, grants, student loans, work-study tuition fee, tuition, special hardship assistance, compensation, green form, various forms of complementarity, and formed a relatively complete system.

(一) work-study programme

Work-study program is a way of university actively promoting, which means that students with financial difficulties can be some material assistance and exercise ability of these students to earn their own living, preventing some students for nothing, just reach for money habits, develop students ' spirit of self-reliance and self-improvement.

(二) Hardship grants

Hardship grants are effective ways to support students with financial difficulties, and this measure is not just an economic tool, also reflects government concern for college students with financial difficulties, enabling students to feel the warmth of the government and schools. They are profound ideological education.

(三) Scholarships

At present, the college scholarships were established to reward outstanding students, encourage students to make progress. Scholarship has become a main way of material support.

3.2 Building new subvention policy modes of physical education students with family financial difficulties

(一) facilitating the financing legislation and improving the formal system

As the beneficiaries and provider of the system, states have the responsibility to introduce student financial assistance regulations, various means of financing clearly defined, making financing for compliance. Through legislation, we can promote the legalization of the system of student financial assistance to effectively safeguard the legitimate rights and interests of funders and grantees .

(二) Scientific determination of physical education students with family financial difficulties

Economic hardship of the family is a relative, dynamic and complex social phenomena. In defining the students with family financial difficulties, the government should develop a dynamics, elasticity, classifications and standards, and give special care according to case-specific such as single parent families, the family of three lonely people, physically disabled students, school survey responses in a timely manner, a flexible policy for students in case to provide special financial support.

(三) Importance to the spirit of the financing

First, we should guide students who actively participate in community activities, volunteer activities, enhance the return on their country and return the society's sense of responsibility and 
mission. encouraging students with financial difficulties to participate with the school club activities, strengthening cooperation and exchanging with other students, to build themselves, servicing to others on their platform, so as to foster their confidence and creativity;

Second, it is better to teach one how to fish than give him fish. Strengthening survival skills and social adaptive ability training for physical education students with family financial difficulties, and enable students to practice self, self growth, to their ability to provide for themselves, to survive basic skills.

Third, take man as the foundation. While working in finance use human works, and appropriate use of covert financial support, respect for privacy and protect self-esteem of them from harm.

\section{References}

[1]H.gao.Psychological problems and Countermeasures in the presence of poor students in Colleges and Universities $[\mathrm{J}]$.Journal of Shandong Youth University of Political Science2006， 3（2）: 12-14.

[2]H.N.he.Thinking of Ideological and political education of students in the problems and Countermeasures of University family economic difficulties [ $\mathrm{J}]$.Journal of Southwest Agricultural University: Social Science edition,2005, 3 (4) : 183-186.

[3]X.B.xiao.Thoughts on the education of college students in Higher School of economic management difficulties [J].China Metallurgical Education2005, 5 (4) : 42-44.

[4] X.Q.he.Some thoughts on psychological health education of students with financial difficulties.[J] .Journal of Dongguan University of Technology, 2004, 11 (4) : 77-79.

[5]X.S.zhang .On college poor students education guidance and assistance [ J ] .Journal of Nantong Institute of Technology: Social Science Edition, 2002， 18 (4) : 99-100. 